\title{
FLOOD MAGNITUDE AND FREQUENCY OF MAIN DITCH AT THE CULVERT ON NEW JERSEY ROUTE 44 AND AT THE CONRAIL CULVERT DOWNSTREAM, WEST DEPTFORD TOWNSHIP, GLOUCESTER COUNTY, NEW JERSEY
}

\section{U.S. GEOLOGICAL SURVEY}

Open-File Report 96-325

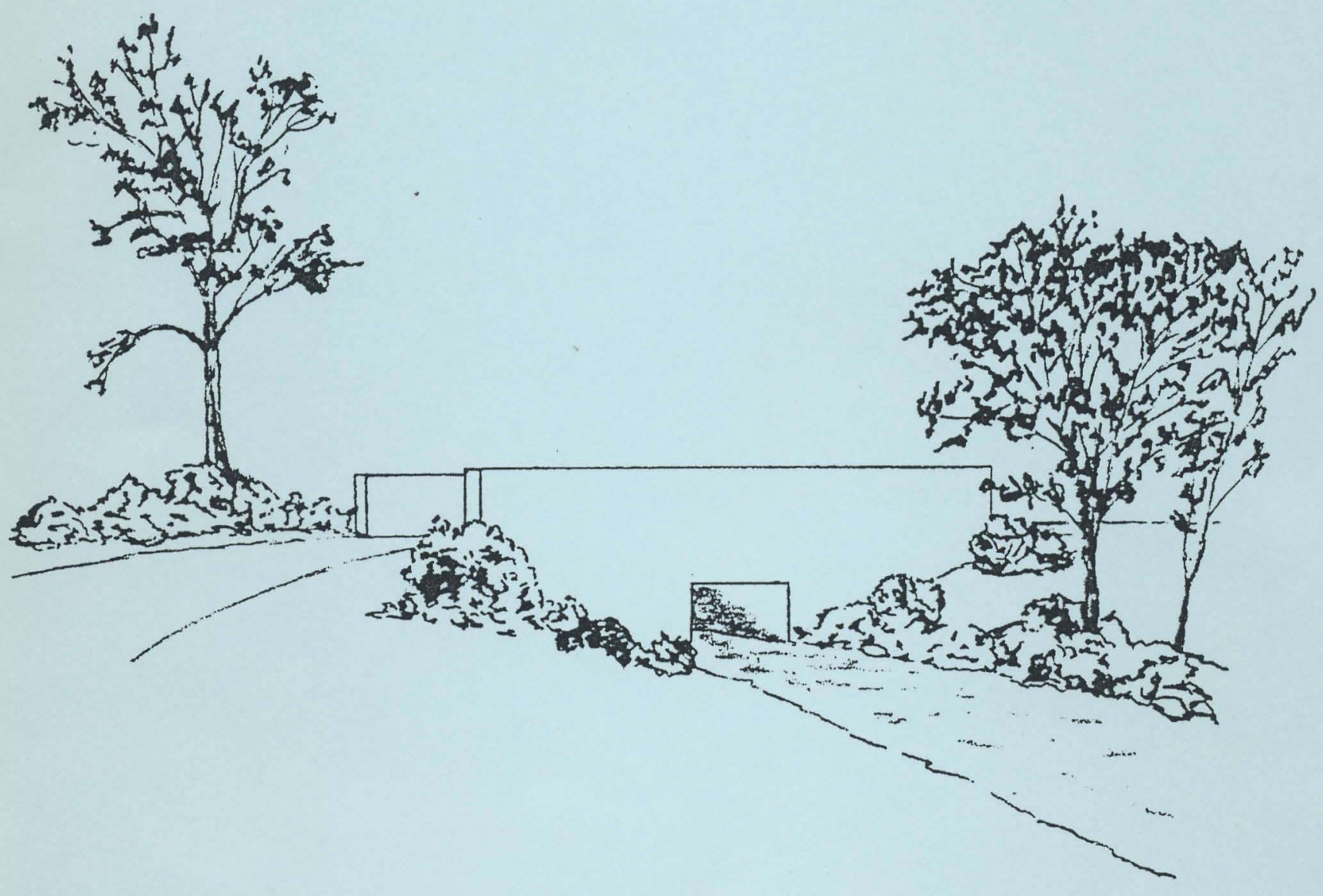

Prepared in cooperation with the NEW JERSEY DEPARTMENT OF TRANSPORTATION

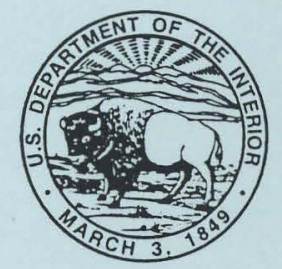




\section{FLOOD MAGNITUDE AND FREQUENCY OF MAIN DITCH AT THE CULVERT ON NEW JERSEY ROUTE 44 AND AT THE CONRAIL CULVERT DOWNSTREAM, WEST DEPTFORD TOWNSHIP, GLOUCESTER COUNTY, NEW JERSEY}

By Thomas Barringer

U.S. GEOLOGICAL SURVEY

Open-File Report 96-325

Prepared in cooperation with the NEW JERSEY DEPARTMENT OF TRANSPORTATION

West Trenton, New Jersey 


\title{
U.S. DEPARTMENT OF THE INTERIOR \\ BRUCE BABBIT, Secretary
}

\author{
U.S. GEOLOGICAL SURVEY
}

Gordon P. Eaton, Director

For additional information write to:

District Chief

U.S Geological Survey Mountain View Office Park

810 Bear Tavern Road, Suite 206

West Trenton, NJ 08628
Copies of this report can be obtained from:

U.S Geological Survey Earth Science Information Center Open-File Reports Section Box 25286, MS 517

Denver Federal Center

Denver, CO 80225 


\section{CONTENTS}

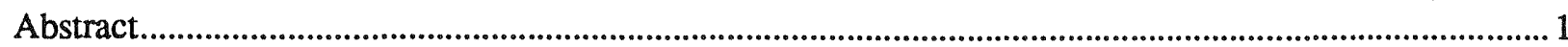

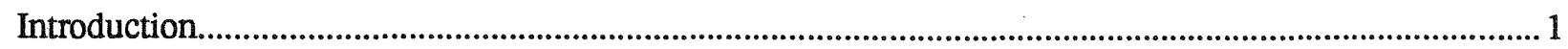

Methods for determining flood magnitude and frequency .................................................................... 1

New Jersey Department of Environmental Protection Special Report 38 method...................................... 3

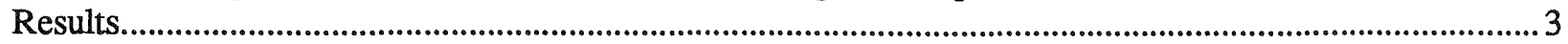

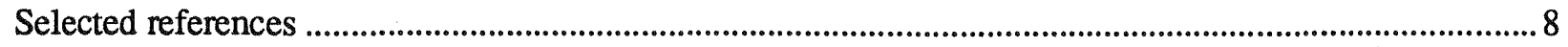

\section{ILLUSTRATIONS}

Figure 1. Map showing location of Main Ditch at the culvert at milepost 8.3 on New Jersey Route 44 and at the Conrail culvert 0.21 miles downstream and associated drainage basins, West Deptford Township, New Jersey

\section{TABLES}

Table 1. Explanatory variables for the flood-magnitude and -frequency analysis of Main Ditch at the culvert on New Jersey Route 44, West Deptford Township, New Jersey

2. Explanatory variables for the flood-magnitude and -frequency analysis of Main Ditch at the Conrail culvert downstream from the culvert on New Jersey Route 44, West Deptford Township, New Jersey.

3. Estimates of flood magnitudes for selected flood frequencies, Main Ditch at the culvert on New Jersey Route 44, West Deptford Township, New Jersey

4. Estimates of flood magnitudes for selected flood frequencies, Main Ditch at the Conrail culvert downstream from the culvert on New Jersey Route 44, West Deptford Township, New Jersey. 


\section{CONVERSION FACTORS}

Multiply

foot (ft)

mile (mi)

square mile $\left(\mathrm{mi}^{2}\right)$

foot per mile ( $\mathrm{ft} / \mathrm{mi}$ )

cubic foot per second $\left(\mathrm{ft}^{3} / \mathrm{s}\right)$
By

0.3048

1.609

2.590

0.189

0.0283
To obtain

meter

kilometer

square kilometer

meter per kilometer

cubic meter per second 


\title{
FLOOD MAGNITUDE AND FREQUENCY OF MAIN DITCH AT THE CULVERT ON NEW JERSEY ROUTE 44 AND AT THE CONRAIL CULVERT DOWNSTREAM, WEST DEPTFORD TOWNSHIP, GLOUCESTER COUNTY, NEW JERSEY
}

\author{
By Thomas Barringer
}

\begin{abstract}
The magnitude and frequency of floods at Main Ditch at the culvert on New Jersey Route 44 at milepost 8.3 and at the Conrail culvert 0.21 miles downstream, in West Deptford Township, New Jersey, were determined by using the New Jersey Department of Environmental Protection Special Report 38 method. Flood-magnitude and -frequency estimates, as well as drainage-basin characteristics, are included in this report. The 100-year-flood estimates are 285 cubic feet per second at the culvert on New Jersey Route 44 and 345 cubic feet per second at the Conrail culvert.
\end{abstract}

\section{INTRODUCTION}

Information on the magnitude and frequency of floods is critical to the planning and design of highway culverts and bridges. Such information is not readily available for many stream crossings in New Jersey. To fulfill this information need, the U.S. Geological Survey (USGS), in cooperation with the New Jersey Department of Transportation, began an analysis of flood data from stream-crossing sites on New Jersey streams.

This report presents results of the analysis for Main Ditch at the culvert on New Jersey Route 44 (Crown Point Road) at milepost 8.3 and at the Conrail culvert 0.21 miles downstream, in West Deptford Township, New Jersey (fig. 1). The drainage area upstream from Route 44 site is $0.48 \mathrm{mi}^{2}$, and the drainage area upstream from the Conrail culvert site is $0.55 \mathrm{mi}^{2}$. A field reconnaissance was performed on February 23, 1995, to verify the locations of drainage-basin divides and basin characteristics. Both sites discussed in this report are subject to occasional tidal effects; these effects were not considered in the calculations of flood magnitude and frequency.

The flood-insurance study for West Deptford Township (Federal Emergency Management Agency, 1981) does not include a detailed study of this stream; therefore, flood discharges were not determined previously.

\section{METHODS FOR DETERMINING FLOOD MAGNITUDE AND FREQUENCY}

Various widely used methods for calculating flood magnitude and frequency were considered for use in determining the flood magnitudes that are likely to be exceeded at these sites within a given number of years (recurrence interval). The rational method (Chow and others, 1988), New Jersey Department of Environmental Protection (NJDEP) Special Report 38 method (Stankowski, 1974), the U.S. Soil Conservation Service (SCS) Technical Release 55 (TR-55) method (U.S. Soil Conservation Service, 1986), a variation of the USGS transfer method (New Jersey Department of Environmental Protection, 1993), and the USGS index-flood method (Thomas, 1964) were all considered for use in determining the flood magnitude and frequency of Main Ditch at the subject sites in West Deptford Township, New Jersey. 


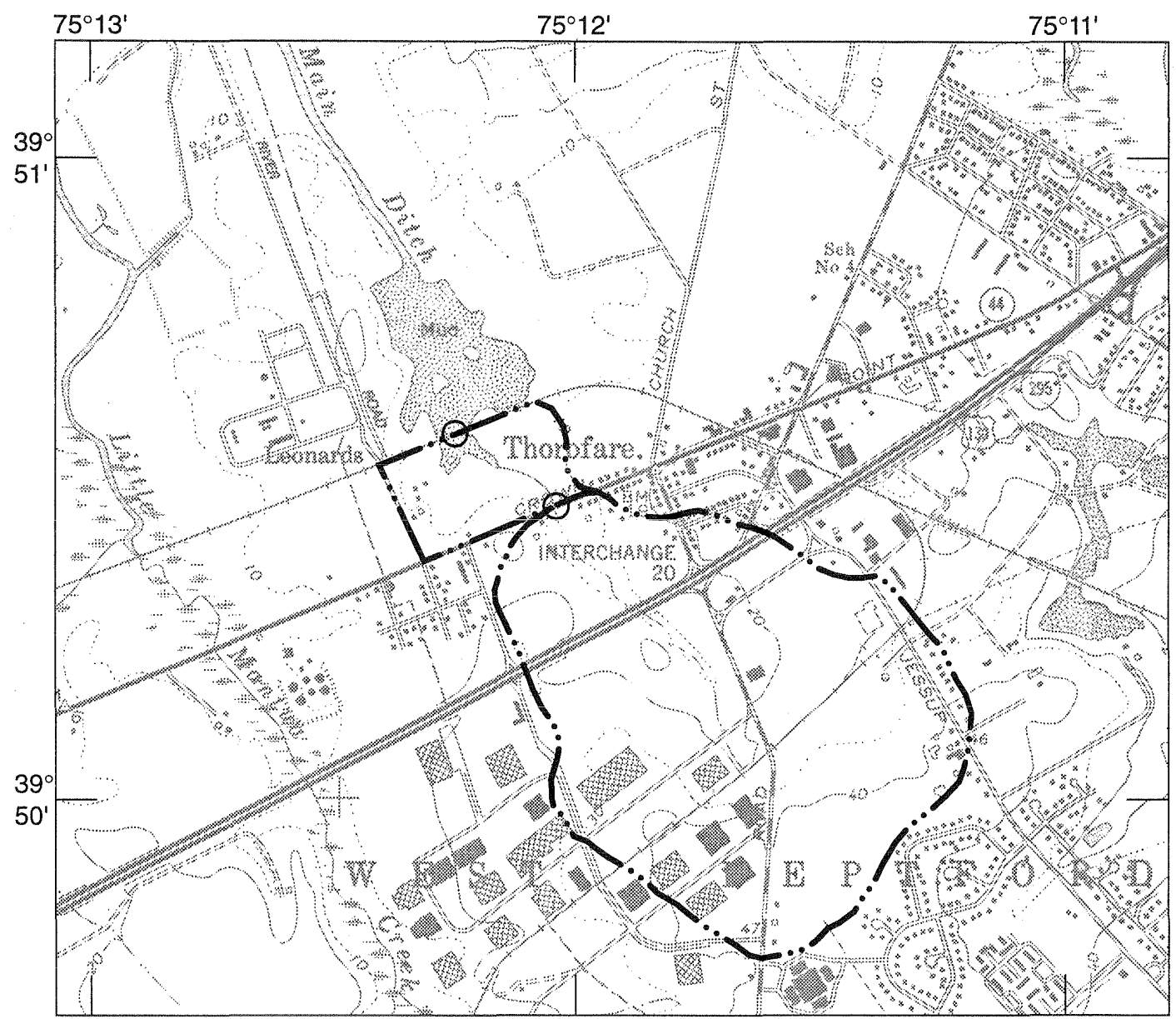

Base from U.S. Geological Survey 1:24,000, quadrangle, Woodbury, 1967, photorevised 1986

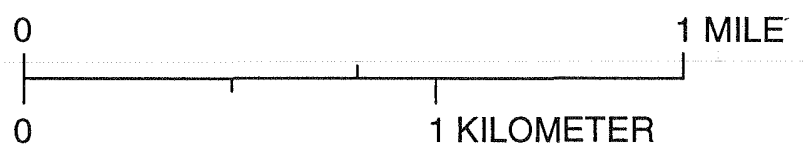

\section{EXPLANATION}

DRAINAGE-BASIN BOUNDARY

O CULVERT SITE

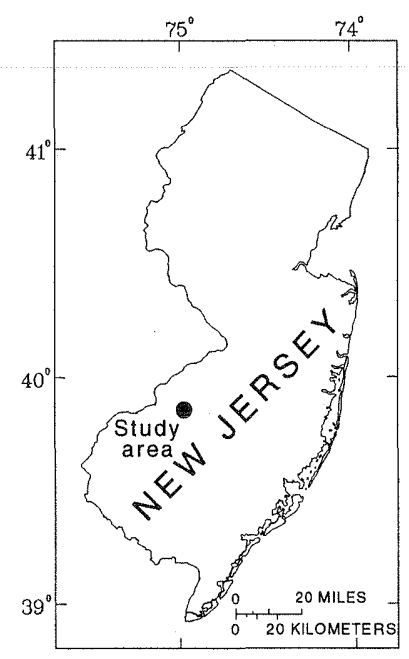

Figure 1. Location of Main Ditch at the culvert at milepost 8.3 on New Jersey Route 44 and at the Conrail culvert 0.21 miles downstream and associated drainage basins, West Deptford Township, New Jersey. 


\section{NEW JERSEY DEPARTMENT OF ENVIRONMENTAL PROTECTION SPECIAL REPORT 38 METHOD}

The New Jersey Department of Environmental Protection Special Report 38 method (SR 38) (Stankowski, 1974) was chosen to estimate peak streamflows at the subject sites. Estimates made with the SR 38 method are based on a set of regression equations in which the predictors are drainage-basin area, main-channel slope, surface storage, and amount of impervious cover.

Estimates made with this method were compared with estimates made using several other methods. Estimates made with the USGS transfer method required the use of flood data from nearby streamflow-gaging stations located in basins that have drainage areas and other basin characteristics similar to those at the subject sites. Peak-flow estimates also were made by using the rational and TR-55 methods.

The estimates of the 100-year flood made for the Route 44 site by using the USGS transfer method with data from station 01467317 (South Branch of Newton Creek at Haddon Heights, New Jersey) were 1.2 times that made by using the SR 38 method. Similarly, estimates for the Conrail site made with the USGS transfer method were 1.2 times that made by using the SR 38 method. The estimate made by using the SR 38 method agreed closely with the estimates made by using the USGS transfer method; therefore, the SR 38 estimates were chosen for this analysis.

\section{RESULTS}

Flood data from nearby streamflow- or crest-stage gaging stations provide a good indication of the flood magnitude and frequency that can be expected at an ungaged site, particularly when drainage area and other basin characteristics are similar. In this study, estimates were obtained by using the NJDEP SR 38 method and compared with estimates made by using the USGS transfer method. Flood data collected at three nearby streamflow-gaging stations (Newton Creek at Collingswood, New Jersey, 01467305; South Branch Newton Creek at Haddon Heights, New Jersey, 01467317; and West Branch Cohansey River at Seeley, New Jersey, 01412500) were used in applying the USGS transfer method. These three stations were chosen from among other nearby stations because their drainage-basin characteristics are most similar to those at the culvert sites. Tidal effects at the two culvert sites were not considered.

The explanatory variables used in applying the SR 38 method at the culvert sites are listed in tables 1 and 2. The flood-magnitude and -frequency estimates for the subject sites are shown in tables 3 and 4 . The estimate of the 100-year flood discharge at the culvert at New Jersey Route 44 site is $285 \mathrm{ft}^{3} / \mathrm{s}$; that for the Conrail culvert site is $345 \mathrm{ft}^{3} / \mathrm{s}$. 
Table 1. Explanatory variables for the flood-magnitude and -frequency analysis of Main Ditch at the culvert on New Jersey Route 44, West Deptford Township, New Jersey

Drainage area: 0.48 square miles

Latitude: $39^{\circ} 50^{\prime} 28^{\prime \prime}$

Longitude: $75^{\circ} 12^{\prime} 03^{\prime \prime}$

Highway: New Jersey Route 44

Milepost: 8.3

U.S. Geological Survey 7-1/2-minute quadrangle: Woodbury, N.J.-Pa.

\begin{tabular}{llcl}
\hline \multicolumn{1}{c}{ Variable } & & Value & \\
\hline Drainage area & $=$ & 0.48 & Unit \\
Main-channel slope & $=$ & 46.7 & feet per mile \\
Surface-storage index & $=$ & 1.0 & percent \\
Total stream length & $=$ & 1.00 & mile \\
Population density (1990) & $=$ & 1,076 & persons per square mile \\
Impervious cover & $=$ & 13 & percent \\
Lake and swamp area & $=$ & 0.0 & percent \\
\hline
\end{tabular}


Table 2. Explanatory variables for the flood-magnitude and -frequency analysis of Main Ditch at the Conrail culvert downstream from the culvert on New Jersey Route 44, West Deptford Township, New Jersey

Drainage area: 0.55 square miles

Latitude: $39^{\circ} 50^{\circ} 35^{\prime \prime}$

Longitude: $75^{\circ} 12^{\prime} 16^{\prime \prime}$

Highway: Conrail culvert east of the culvert at New Jersey Route 44

Milepost: 8.3

U.S.Geological Survey 7-1/2-minute quadrangle: Woodbury, N.J.-Pa.

\begin{tabular}{llcl}
\hline \multicolumn{1}{c}{ Variable } & & Value & \multicolumn{1}{c}{ Unit } \\
\hline Drainage area & $=$ & 0.55 & square miles \\
Main-channel slope & $=$ & 38.0 & feet per mile \\
Surface-storage index & $=$ & 1.0 & percent \\
Total stream length & $=$ & 1.19 & mile \\
Population density (1990) & $=$ & 1,076 & persons per square mile \\
Imperyious cover & $=$ & 13 & percent \\
Lake and swamp area & $=$ & 0.0 & percent \\
\hline
\end{tabular}


Table 3. Estimates of flood magnitudes for selected flood frequencies, Main Ditch at the culvert on New Jersey Route 44, West Deptford Township, New Jersey

[Q, flood-magnitude estimates in cubic feet per second along with number indicating frequency of the recurrence interval in years; NJDEP SR, New Jersey Department of Environmental Protection Special Report]

Drainage area: 0.48 square miles

Latitude: $39^{\circ} 50^{\prime} 28^{\prime \prime}$

Longitude: $75^{\circ} 12^{\prime} 03^{\prime \prime}$

Highway: New Jersey Route 44

Milepost: 8.3

U.S.Geological Survey 7-1/2-minute quadrangle: Woodbury, N.J.-Pa.

\begin{tabular}{lllllll}
\hline Estimating method & Q2 & Q5 & Q10 & Q25 & Q50 & Q100 \\
\hline NJDEP SR 38 & 66 & 99 & 133 & 186 & 227 & 285 \\
\hline
\end{tabular}


Table 4. Estimates of flood magnitudes for selected flood frequencies, Main Ditch at the Conrail culvert downstream from the culvert on New Jersey Route 44, West Deptford Township, New Jersey

[Q, flood-magnitude estimates in cubic feet per second along with number indicating frequency of the recurrence interval in years; NJDEP SR, New Jersey Department of Environmental Protection Special Report]

Drainage area: 0.55 square miles

Latitude: $39^{\circ} 50^{\prime} 35^{\prime \prime}$

Longitude: $75^{\circ} 12^{\prime} 16^{\prime \prime}$

Highway: Conrail culvert below New Jersey Rt. 44

Milepost: 8.3

U.S.Geological Survey 7-1/2-minute quadrangle: Woodbury, N.J.-Pa.

\begin{tabular}{lllllll}
\hline Estimating method & Q2 & Q5 & Q10 & Q25 & Q50 & Q100 \\
\hline NJDEP SR 38 & 80 & 120 & 162 & 226 & 276 & 345 \\
\hline
\end{tabular}




\section{SELECTED REFERENCES}

Chow, V.T., Maidment, D.R., and Mays, L.W., 1988, Applied hydrology: New York, McGraw-Hill, 572 p.

Federal Emergency Management Agency, 1981, Flood insurance study, Township of West Deptford, New Jersey: Federal Emergency Management Agency, December, 1981, 18 p., 13 pls.

New Jersey Department of Environmental Protection, 1993, Technical manual for stream encroachment permits: New Jersey Department of Environmental Protection and Energy, Land Use Regulation Program, Bureau of Inland Regulation, Bureau of Coastal Regulation, May 1993, 100 p., 6 app.

Stankowski, S.J., 1974, Magnitude and frequency of floods in New Jersey with effects of urbanization: New Jersey Department of Environmental Protection, Special Report 38, $46 \mathrm{p}$.

Thomas, D.M., 1964, Floods in New Jersey, magnitude and frequency: New Jersey Department of Conservation and Economic Development, Water Resources Circular 13, 145 p.

U.S. Soil Conservation Service, 1986, Urban hydrology for small watersheds: Engineering Division Technical Release 55, Washington, D.C., 162 p. 